\title{
Keskusteluryhmässä jaettavan vertaistiedon ja vertaistuen merkitys sosiaalisesti vetäytyneiden henkilöiden itsemurha- keskusteluissa
}

\author{
Ari Haasio \\ Seinäjoen ammattikorkeakoulu \\ ari.haasio@seamk.fi \\ https://orcid.org/0000-0003-3723-4890 \\ Mari Salminen-Tuomaala \\ Seinäjoen ammattikorkeakoulu \\ mari.salminen-tuomaala@seamk.fi \\ https://orcid.org/0000-0002-8216-9840
}

Tässä artikkelissa käsitellään suomalaisten sosiaalisesti vetäytyneiden henkilöiden eli hikikomoreiden itsemurhaan liittyviä tiedontarpeita ja aiheeseen liittyvää keskustelua Ylilaudan Hikikomero-keskustelupalstalla. Keskeiset tutkimuskysymykset ovat: Mitä tiedontarpeita keskustelijoilla on itsemurhaan liittyen ja millaisia psyykkisiä ja sosiaalisia itsemurhaa edistäviä vaikuttimia verkkokeskusteluissa voidaan havaita? Artikkelin teoreettinen viitekehys perustuu Reijo Savolaisen elämäntavan teoriaan. Yksi artikkelin keskeisistä tavoitteista on eksplikoida disnormatiivisen informaation esiintymistä verkossa vertaistiedon ja vertaistuen muodossa.

Artikkeli perustuu Ylilaudan sosiaalisesti vetäytyneiden henkilöiden Hikikomero-keskustelupalstan itsemurha-aiheisiin viesteihin $(\mathrm{n}=2124)$. Aineiston analyysissä on sovellettu kvantitatiivista ja kvalitatiivista sisällönanalyysiä.

Tulosten perusteella vertaistuen ja vertaistiedon merkitys itsemurhan suunnittelussa on suuri. Keskustelupalstalta saadaan vastakaikua ja ymmärrystä omille mielipiteille. Valitettavaa on se, että useissa tapauksissa saatu vertaistuki ja vertaistieto ovat luonteeltaan negatiivisia ja rohkaisevat yrittämään itsemurhaa. Arvottomuuden ja avuttomuuden kokemus sekä tunne oman elämänhallinnan menettämisestä motivoivat itsemurhan tekemiseen. Toisaalta rohkeuden puute ja huoli läheisten surusta taas ovat itsemurhaa estäviä tekijöitä.

Asiasanat: vertaistieto, vertaistuki, keskusteluryhmät, hikikomorit, sosiaalinen vetäytyminen

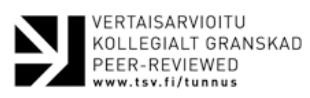

Artikkeli on lisensoitu Creative Commons Nimeä-EiKaupallinen-JaaSamoin 4.o Kansainvälinen -lisenssillä 


\section{Johdanto}

Suomessa tehtiin vuonna 2018 kaikkiaan 810 itsemurhaa (Tilastokeskus 2019). Vuoden 2016 tilastojen mukaan nuorten 15-24-vuotiaiden itsemurhakuolleisuus oli Suomessa muita EU-maita keskimäärin korkeampaa, peräti 12 prosenttia kaikista itsemurhan tekijöistä maassamme on 15-24-vuotiaita. (Itsemurhat 2019; Kuolemansyytilasto 2018) Vaikka itsemurhien kokonaismäärä maassamme on viime vuosina ollut laskussa, nuorten osalta vastaavaa kehitystä ei ole havaittavissa (Kuolemansyytilasto 2018).

Salmanin ym. (2014) mukaan keskeisiä itsemurhan motiiveja olivat masennus, ahdistus ja epätoivoisuus. Myös sosiaalinen vetäytyminen on kansainvälisissä tutkimuksissa havaittu merkittäväksi itsemurha-alttiutta lisääväksi tekijäksi (esim. Uchida 2010; Chu ym. 2015; Yong \& Nomura 2019).

Me-säätiön (2018) tekemän selvityksen mukaan vuonna 2018 Suomessa oli yli 65000 syrjäytynyttä $15^{-29}$-vuotiasta henkilöä. Osa heistä on sosiaalisesti vetäytyneitä, joita kansainvälisessä tutkimuksessa kutsutaan alun perin japanilaisella käsitteellä hikikomori. Nämä nuoret ja nuoret aikuiset katkaisevat tyypillisesti osan tai kaikki siteet ulkomaailmaan ja heidän elämänsä keskiössä ovat esimerkiksi tietokonepelit. Kommunikointi tapahtuu usein verkon välityksellä ja pitkään jatkunut kiusaaminen alaluokilta asti sekä yksinäisyys ovat näille henkilöille yhteisiä nimittäjiä (Haasio 2015a). Esimerkiksi yksinäisyyden on havaittu nostavan nuorten itsemurhariskiä (vrt. Lassgaard, Goossens \& Elklit 2011; Schinka ym. 2013). On kuitenkin syytä huomata, että syrjäytyminen ja sosiaalinen vetäytyminen eivät ole synonyymejä. Sosiaalisesti vetäytynyt henkilö pidättäytyy sosiaalisesta kanssakäymisestä ja on näin syrjäytynyt. Osa syrjäytyneistä taas ei ole sosiaalisesti vetäytyneitä, mutta he ovat syrjäytyneitä esimerkiksi työelämästä tai opinnoista. Syrjäytymistä aiheutuu esimerkiksi työuran epävakaudesta, heikosta osaamistasosta, pienituloisuudesta, heikoista asuinoloista terveydellisistä ongelmista tai perheen hajoamisesta. Käsite on monimuotoinen ja siihen ei ole olemassa yhtä kattavaa määritelmää. (Marttunen, Haravuori \& Santalahti 2014.) Linnakankaan ja Suikkasen (2004) mukaan nuorten syrjäytyminen näkyy "koulukiusaamisena, levottomuutena, erilaisena häiriökäyttäytymisenä, psyykkisinä oireina, päihteiden riskikäyttönä, väkivaltana ja sopeutumattomuutena”. Sosiaalisesti vetäytyneet sen sijaan eivät välttämättä täytä näitä kriteerejä ja sosiaalisesti vetäytyneelle hikikomorille on olemassa tarkempi määritelmä, jossa keskeistä on eristäytyminen kotiin ja pidättäytyminen sosiaalisista kontakteista (esim. Saito 1998; Teo 2010). 
Yksi verkon lieveilmiöistä on haitallisen tiedon jakaminen. Haasio (2015a) kutsuu tätä disnormatiiviseksi informaatioksi, Lloyd ja Burnett puolestaan (2020) puhuvat pimeästä tiedosta (Dark Knowledge). Sillä tarkoitetaan informaatiota, joka on yhteiskunnan normien, arvojen ja eräissä tapauksissa myös lainsäädännön vastaista. Kumpikin käsite viittaa henkilön tai yhteiskunnan kannalta haitalliseen ja moraalisesti arveluttavaan informaatioon, olkoonkin että nämä kaksi käsitettä eivät ole sisällöllisesti täysin yhteneviä. Itsemurhan suunnitteluun liittyvät kysymykset ovat hyvä esimerkki disnormatiivisen tiedon tarpeista ja niihin liittyvästä tiedon jakamisesta. Puhuttiinpa disnormatiivisesta informaatiosta tai pimeästi tiedosta, ne kumpikin tuovat esiin ajatuksen vertaistiedon merkityksestä tiedon tyyppinä sekä vertaistuen eräänä informaation lajina, joka on luonteeltaan yhteiskunnan arvojen vastaista, jopa haitallista. Haasio, Harviainen ja Savolainen (2020) antavat tämän tyyppisestä informaatiosta esimerkin huumeiden käyttöön liittyvästä opastuksesta; kokeneempi huumeiden käyttäjä neuvoo vasta-alkajaa esimerkiksi annostelussa yliannostuksen välttämiseksi. Ruokolainen (2018) puolestaan toteaa turvapaikanhakijoiden turvautuvan epäviralliseen disnormatiiviseen informaatioon, jota voidaan luonnehtia myös vertaistiedoksi. Disnormatiivisen informaation tai pimeän tiedon voidaankin katsoa pääsääntöisesti olevan vertaistietoa tai -tukea, koska sitä ei saa virallisia kanavia pitkin vaan lähtökohtaisesti saman toiseuden jakavilta henkilöiltä.

Kyse on samalla vertaistiedon hankkimisesta ja sen jakamisesta sekä osin myös vertaistuen etsimisestä. Disnormatiivisen informaation saralta on tehty vain vähän empiiristä tutkimusta (Haasio 2015a; Haasio, Harviainen \& Savolainen 2020) käsitteen todentamiseksi ja sen avaamiseksi. Sama koskee Burnettin ja Lloydin (2020) pimeän tiedon käsitettä, jota käsittelevää empiriaa ei toistaiseksi ole. Tämä tutkimus pyrkii osaltaan avaamaan yhtäältä disnormatiivisen informaation luonteeseen ja ilmenemismuotoihin liittyvää problematiikkaa ja toisaalta analysoimaan disnormatiivisen informaation tiedontarpeiden artikulointia ja vertaistiedon ja -tuen merkitystä tämän tyyppisen informaation osalta empiirisen analyysin avulla.

\section{Aiempi tutkimus}

Hikikomori (jap. hikikomorou) tarkoittaa sisäänpäin kääntynyttä ja sillä voidaan viitata joko olotilaan tai yksittäiseen henkilöön (Krysinska 2006; Ohashi 2008). Ilmiö on alun perin japanilainen ja sen on todettu olevan voimakkaasti sidoksissa japanilaiseen kulttuuriin ja maan historiaan (Valaskivi 2012). Ranierin (2018) mukaan hikikomori on nuori tai nuori aikuinen, joka 
eristäytyy kotiinsa pidemmäksi ajaksi ilman ilmeisiä merkkejä psykologisesta ahdingosta tai avoimesta mielenterveyden häiriöstä. Japanissa hikikomoreiksi luokitellaan henkilöt, jotka ovat eristäytyneet vähintään kuuden kuukauden ajaksi perheen ulkopuolisista kontakteista (esim. Saito 1998; Teo 2010). Teon (2010) mukaan hikikomoreiden elämäntavalle on tyypillistä kotikeskeisyys, haluttomuus tehdä töitä tai opiskella sekä oman perheen ulkopuolisten henkilökohtaisten kontaktien puute. Mielenterveyden häiriöt eivät selitä näitä oireita ja niiden on täytynyt jatkua vähintään puoli vuotta.

Hikikomori-ilmiötä on tutkittu runsaasti erityisesti psykiatrisesta näkökulmasta (esim. Ranieri 2015; Sarchione et al. 2015; Tajan 2015; Tan, Lee \& Kato 2020; Kato, Shinfuku \& Tateno 2020). Siihen kohdistunut kulttuurissosiologinen tutkimus on ollut vähäisempää. Hikikomoreiden informaatiokäyttäytymistä (Haasio 2015a; Haasio \& Naka 2019), seksuaalisuutta (Zechner \& Haasio 2016) ja elämäntapaa (Haasio 2018) on käsitelty eräissä artikkeleissa. Vaikka hikikomori-ilmiön on havaittu olevan maailmanlaajuinen (esim. Kato et al. 2012; Suwa \& Suzuki 2013; Kato, Kanba \& Teo 2018), on Japanin ulkopuolella tehdyn tutkimuksen määrä vähäisempi. Ilmiö on alun perin japanilainen ja voimakkaasti sidoksissa japanilaiseen kulttuuriin (Valaskivi 2012; Teo 2010), se on tunnistettu muun muassa Espanjassa (Ovejero, Caro-Cañizares, de León-Martínez,\& Baca-Garcia 2014), Suomessa (Husu \& Välimäki 2017), Italiassa (Ranieri 2015), Etelä-Koreassa, Intiassa ja Yhdysvalloissa (Tajan 2015; Kato, Kanba \& Teo 2018). Uusimmissa tutkimuksissa (esim. Yong \& Nomura 2019) ilmiötä on alettu pitää globaalina.

Uudemmassa japanilaisessa tutkimuksessa hikikomorit on jaoteltu hikikomoreihin (kyōgi no hikikomori) ja kvasi-hikikomoreihin (jun hikikomori) (Tajan, Yukiko \& Pionnié-Sax 2017). Ensin mainittu ryhmä täyttää Teon (2010) mainitsemat kriteerit eristäytymisestä, mutta jälkimmäisellä saattaa olla vielä jossain määrin yhteyksiä ympäröivään yhteiskuntaan (ks. myös Kato, Kanba ja Teo (2019) Kotimaisessa tutkimuksessa tätä elämäntapaa koskevaa havaintoa tukevat esimerkiksi Haasion (2015a; 2018) havainnot informaatiokäyttäytymisestä, arjen rutiineista ja sosiaalisista suhteista. Elämäntapaa koskevien johtopäätösten taustalla on aiemmassa tutkimuksessa tehty verkkokeskusteluihin kohdistunut analyysi, jossa on selvitetty sosiaalisesti vetäytyneiden arkea ja heidän informaatiokäyttäytymistään ennen muuta elämäntavan kontekstissa. Tuo analyysi on perustunut henkilöiden omiin kertomuksiin arjesta Ylilaudan Hikikomero-keskustelupalstalla, josta kerättyä aineistoa on käytetty myös tämän tutkimuksen materiaalina.

Ylilauta on suomalainen kuvalauta ja Hikikomero on yksi sen keskustelupalstoista, joka on masentuneiden ja sosiaalisesti vetäytyneiden oma keskustelufoorumi verkossa. Palvelu on anonyymi ja kuka tahansa voi lukea viestejä 
sekä kirjoittaa ja kommentoida keskusteluihin. Hikikomeron kielenkäyttö ja kommentit saattavat paikoitellen olla rajuja ja alatyylisiä. Ainoa rajoite on se, että palveluun ei saa lähettää laitonta materiaalia ja Hikikomerossa ei saa aliarvioida sosiaalista vetäytyneisyyttä tai kehua tyttö- tai poikaystävällä.

Suomessa sosiaalisesti vetäytyneiden nuorten olemassaolo on havaittu viime vuosina. Heihin kohdistunutta tutkimusta on tehty jossain määrin (Haasio 2015a; Zechner \& Haasio 2016; Husu \& Välimäki 2017; Vainikka \& Harju 2019; Vainikka 2020) vaikka ilmiö on osattu nimetä heikosti. Sosiaalisen vetäytymisen ongelmat, jotka liittyvät hikikomori-ilmiöön, on usein liitetty laajemmin yhteiskunnalliseen syrjäytymiseen ja hikikomori-käsite ei ole vakiintunut kotimaiseen tieteelliseen keskusteluun.

Kato, Kanba ja Teo (2019) toteavat, että hikikomoreilla on keskimääräistä suurempi todennäköisyys tehdä itsemurha 15-39-vuotiaiden japanilaisten keskuudessa tehtyyn tutkimukseen perustuen. Heidän mukaansa itsemurha ja hikikomori-elämäntapa ovat tapoja paeta maailmasta. Myös Yong ja Nomura (2019) ovat todenneet, että hikikomoreilla on havaittavissa keskimääräistä enemmän riippuvuuksiin, pakko-oireisiin ja itsemurha-alttiuteen viittaavaa käyttäytymistä. Kato, Kanba ja Teo (2019) korostavatkin hikikomorien itsemurhiin ja itsemurha-alttiuteen liittyvän tutkimuksen merkitystä yhtenä aihepiirin tarkempaa tutkimusta vaativana osa-alueena. Haasio ja Salminen-Tuomaala (2020) ovat analysoineet verkkokeskustelujen perusteella sosiaalisesti vetäytyneiden suomalaisnuorten itsemurhan tekemiseen liittyviä motiiveja ja esteitä.

Verkossa on runsaasti kansainvälisiä itsemurhiin keskittyneitä sivustoja ja niiden merkitystä itsemurhan tekemisen edistämiseen on tutkittu. Esimerkiksi Marchantin ja kumppaneiden (2017) mukaan verkkofoorumit saattavat edistää itsemurhan toteuttamista ruokkivia ajatuksia. Hikikomoreilla runsaasti havaitulla internet-riippuvuudella ja kohonneella itsemurha-alttiudella on myös alustavasti havaittu olevan positiivinen riippuvuussuhde toisiinsa (Kato et al. 2012). Puhtaasti hikikomoreiden itsemurha-alttiudesta ja verkon keskustelufoorumien vaikutuksesta näiden ajatusten toteuttamiseksi ei ole tehty tutkimusta. Sen sijaan itsemurhiin ja verkon foorumeihin yleisemmällä tasolla liittyviä artikkeleita on kirjoitettu itsemurhiin liittyvän tiedon hankinnasta (Recupero, Harms \& Noble 2008; Hagihara, Miyazaki \& Abe 2012) sekä internetin ja sosiaalisen median käytön runsauden mahdollisesta positiivisesta korrelaatiosta itsemurha-alttiuteen (Sedgwick, Epstein, Dutta \& Ougrin 2019). Myös Padmanathan ym. (2018) havaitsivat internetin itsetuhoisuutta ja itsemurha-aikeita vahvistavan vaikutuksen. 


\section{Tutkimuksen teoreettinen viitekehys}

Tässä artikkelissa käsittelemme suomalaisten sosiaalisesti vetäytyneiden henkilöiden eli hikikomoreiden keskustelupalstallaan esittämiä pohdintoja itsemurhasta tiedon tarpeiden ja ennen muuta vertaistiedon ja -tuen näkökulmasta. Reijo Savolaisen (1993; 1995) kehittämä teoria elämäntavasta arkielämän ei-ammatillista tiedonhankintaa ohjaavana tekijänä on taustaoletuksena. Sen mukaan elämänhallinta eli "asioiden järjestys", joka toteutuu taloudellisten, kulttuuristen ja sosiaalisten rakenteiden rajoissa, on keskeinen tiedonhankintaprosessiin vaikuttava tekijä. Tutkimuksen kohteena olevan ryhmän arki ja heidän elämäntapansa muodostaa melko yhtenevän, kansalaisten keskivertoarjesta poikkeavan yhteisen nimittäjän, jossa keskustelijoilla on heidän kertomansa mukaan saman tyyppisiä elämänhallinnan ongelmia ja toisaalta yhtenevä elämäntapa, joka eksplikoituu sosiaalisena vetäytymisenä. Tätä väitettä tukevat Haasion (2015a; 2018) kotimaisiin hikikomoreihin kohdistuneet tutkimukset. Elämäntavasta johtuva samanlainen toiseus on yhteinen nimittäjä (vrt. Haasio 2015a).

Tutkimuksemme kannalta keskeisiä käsitteitä ovat vertaistieto ja vertaistuki. Vertaistieto on luonteeltaan subjektiivista, joka ilmaisee antajansa mielipiteen, kokemuksen tai näkemyksen jostain asiantilasta (Haasio 2015c). Se perustuu toisen henkilön kokemukseen, luuloon, mielipiteeseen tai arvaukseen. Nylund (2006) on määritellyt vertaistuen samankaltaisessa elämäntilanteessa olevien ihmisten haluksi jakaa kokemuksia ja tietoa toisia kunnioittavassa ilmapiirissä. Vaikka vertaistuki ei ole tietoa termin suppean tulkinnan mukaan, voidaan se Brenda Dervinin (1999) käsitykseen nojautuen ymmärtää informaatioksi, jonka avulla jäsennetään maailmaa. Kyse on kokemusten ja näkemysten jakamisesta, joka voidaan tulkita informaation jakamiseksi. Vertaistuki on usein esimerkiksi terveydellisiin ongelmiin liittyvää, saman sairauden tai muun vastoinkäymisen kohdanneen toiselle antamaa. Esimerkiksi mielenterveysongelmissa siitä saatava apu on usein käyttökelpoista (Repper \& Carter 2011). Naslundin ym. (2016) mukaan mielenterveysongelmista kärsivät ihmiset hakevat enenevästi vertaistukea ja vertaistietoa sosiaalisen median kanavilta, esimerkiksi Facebookista, Twitteristä ja YouTubesta. He jakavat tietoa sairauskokemuksistaan muille ja etsivät neuvoja omaan tilanteeseensa muilta, jotka ovat kokeneet samankaltaisia tilanteita. Tiedon saaminen vertaisilta edistää sekä henkistä että fyysistä hyvinvointia, mutta se voi olla toisinaan myös harhaanjohtavaa. (Gowen ym. 2012, Miller ym. 2015). Se voi olla myös päätöksentekoa tukevaa ja johonkin tiettyyn toimintaan kannustavaa, kuten negatiivisessa mielessä esimerkiksi itsemurhaan rohkaisevaa puhetta (vrt. Haasio \& Salminen-Tuomaala 2020). 
Luottamus vertaistietoon saman taustan jakavien henkilöiden kesken tulee esiin Elfreda Chatmanin (1987; 1990; 1991) tutkimuksissa. Oman viiteryhmän jakamaan informaatioon luotetaan, koska se on tuttujen ihmisten usein kokemusperäistä tietoa. Leivo, Mutanen ja Nieminen-Sundell (2009) ovat todenneet, että nettisukupolvi luottaa vertaistietoon virallista mediaa enemmän, koska "kaverilla ei ole omaa agendaa”. Myös Don Tapscott (2008) on korostanut vertaistiedon merkitystä nettisukupolven informaatiokäyttäytymisessä samasta syystä. Lisäksi sosiaalisen median ryhmien, foorumeiden ja chattien kautta saadaan mielenkiintoista, tarinallista vertaistietoa (Naslund ym. 2014). Ne voivat mahdollistaa sensitiivisistä aiheista keskustelemisen (Kummervold ym. 2002) ja anonymiteetin säilymisen (Highton-Williamson ym. 2015). Positiivisena koetaan se, että on mahdollista valita, haluaako itse välittää vertaistietoa vai osallistua pelkästään vertaistuen saajana (Naslund ym. 2014).

Vertaistieto voi olla myös luonteeltaan vahingollista tai rohkaista ei-toivottuun käyttäytymiseen (Haasio 2015b), kuten äärimmillään tässä artikkelissa käsiteltyyn itsemurhaan.

Vertaistiedon merkitys on tullut esiin myös esimerkiksi rikolliseen toimintaan liittyvässä tiedonhankinnassa, jota on selvitetty huumekauppaa ja huumeiden käyttöön liittyviä tiedontarpeita koskevassa tutkimuksessa (Haasio, Harviainen \& Savolainen 2020). Aiemmassa hikikomoreihin kohdistuneessa tutkimuksessa on tullut ilmi, että vertaistietoa pidetään luotettavana tiedon tyyppinä (Haasio 2015a; 2015b).

\section{Tutkimusaineisto, tutkimuskysymykset ja tutkimusetiikka}

Tutkimusaineisto on kerätty $\mathbf{1 5 . 5 . 2 0 2 0}$ Ylilauta.org-keskustelufoorumin Hikikomero-palstalta (http://ylilauta.org/hikky). Aineistoon sisältyy 42 itsemurha-aineista keskustelulankaa, joissa on yhteensä 2589 viestiä. Analyysiin otettiin mukaan 2124 viestiä, joissa käsiteltiin itsemurhaa. Osassa viestejä keskustelu harhautui esimerkiksi harrasteisiin ja muihin teemoihin (465 kpl). Nämä viestit jätettiin analyysin ulkopuolelle. Laajin yksittäinen viestiketju "Oletko koskaan yrittänyt itsemurhaa" sisälsi kaikkiaan 918 viestiä.

Tutkimuskysymykset voidaan kiteyttää seuraavasti:

1. Mitä teemoja itsemurhaan liittyvissä keskusteluissa käsitellään?

2. Miten vertaistiedon ja -tuen tarve ilmenee verkkokeskusteluissa? 
Aineiston analyysissä on sovellettu kvantitatiivista ja kvalitatiivista sisällönanalyysiä. Kvantitatiivisen sisällönanalyysin avulla luotiin yleiskuva aineiston keskeisestä sisällöstä ja keskusteluaiheiden suosituimmuudesta. Kvalitatiivisen analyysin avulla pyrittiin löytämään niitä argumentteja, näkökulmia ja ajatuksia, joita keskustelijat toivat esiin itsemurhan eri teemoihin liittyen painottaen vertaistiedon ja -tuen merkitystä.

Aineisto analysoitiin ensiksi kvantitatiivista sisällönanalyysiä noudattaen jaottelemalla viestit 12 pääryhmään, jotka muodostettiin aineistolähtöiseen teoriaan pohjautuen (vrt. Glaser \& Strauss 1967) aineiston ensimmäisen läpiluvun jälkeen. Näin luotiin seuraavat kategoriat:

1. Itsemurhan toteutus ja suunnittelu

2. Itsemurhatapa ja välineet

3. Kuolema yleisesti

4. Avautuminen itsemurhasta

5. Itsemurhan tekemisen esteet

6. Itsemurhaa vastustavat kommentit

7. Itsemurhan motiivit

8. Itsemurhaan kannustaminen

9. Kokemukset itsemurhan yrittämisestä

10. Jumala ja uskonnot

11. Trollaus

12. Muut

Lopullisesta analyysistä jätettiin pois luokka 12 (muut), koska viestien aihepiirit eivät liittyneet tutkittavaan teemaan.

Koska kysymys on kuvalaudasta (engl. image board), on kirjoittajilla mahdollisuus liittää viestien yhteyteen kuvia ja erilaisia meemejä eli "internet-ilmiöitä, toisin sanoen internetin välityksellä leviäviä kulttuurisia ideoita ja yksiköitä, joille on tyypillistä toisto ja variaatio" (Heimo 2013).

Tällaisia ovat esimerkiksi erilaiset humoristiset kuvamanipulaatiot, jotka leviävät verkossa. Näitä meemejä ja muita kuvia ei ole otettu mukaan aineiston sisällönanalyysiin ja analyysi perustuu puhtaasti tekstiaineistoon. Meemejä on käytetty aineistossa lähinnä kuvaamaan tunnetiloja tekstin yhteydessä tai itsenäisesti aloittajan lähettämään viestiin vastattaessa esimerkiksi surullisten tunteiden osoituksena.

Tutkimuksen aihepiiri on erittäin arkaluontoinen ja sen vuoksi tutkimuseettisiin kysymyksiin on kiinnitetty erityistä huomiota. Tutkimusaineisto on kerätty anonyymistä palvelusta ja kirjoittajien henkilöllisyyttä on käytännössä mahdotonta selvittää. He saattavat korkeintaan itse viitata viesteissä sukupuoleen, ikään, asuinpaikkaan tai muihin identifioiviin muuttu- 
jiin. Tämän tyyppiset maininnat on suodatettu analyysivaiheessa pois tekstilainoista. Turtiainen ja Östman (2009) ovat korostaneet, että tutkittavien anonymiteetin täytyy aina säilyä. Koska viestit on julkaistu kaikille avoimessa keskusteluryhmässä, niiden käyttöön ei Helasvuon, Johanssonin ja Tanskasen (2014) mukaan tarvita erillistä tutkimuslupaa. Myös Järvinen-Tassopouloksen (2011) ja Whitemanin (2012) näkemykset aineiston avoimuudesta tukevat tätä. Palvelun anonymiteetin johdosta sen voidaan katsoa olevan vapaasti tutkijoiden käytössä ilman erillistä lupahakemusta tai ilmoitusta tutkimuksen suorittamisesta. Robert Kozinets $(2010 ; 2015)$ on todennut, että verkko on luonteeltaan julkinen, ei yksityinen foorumi.

Terveyteen liittyvien kysymysten ohella esimerkiksi huumeiden käyttöön ja huumekulttuuriin liittyvät verkkomateriaaliin perustuvat tutkimukset käsittelevät samalla tavalla arkaluontoisia aiheita esimerkiksi tutkittaessa pimeän netin (Dark Web) yhteisöjä. Näissä tutkimuksissa lähtökohtana on tutkittavien kunnioittaminen ja verkkoyhteisöön sekä keskustelijoihin kohdistuvien mahdollisten haittojen minimointi noudattamalla täyttä anonymiteettiä. (vrt. Martin \& Christie 2016; Ferguson 2017; Harviainen et al. 2021.)

\section{Itsemurha-aiheisten keskustelujen aihepiirit}

Verkkokeskusteluiden kolme yleisintä aihepiiriä olivat itsemurhan toteutus ja suunnittelu (30,3\%), itsemurhatapa ja välineet (25,9\%) ja kuolema yleisesti $(14,4 \%)$. Itsemurhan toteuttamista ja suunnittelua koskevat viestit taas olivat kuvauksia siitä, kuinka kirjoittajat tekevät itsemurhan (esim. aika ja paikka). Eräissä tapauksissa kuvattiin myös viimeiseen hetkeen liittyviä rituaaleja, joita henkilö suunnitteli noudattavansa, kuten sikarin polttaminen, omien käytännön asioiden järjestäminen kuntoon ennen itsemurhaa tms. Moni kirjoittaja pohti sitä, mikä ajankohta olisi soveliain itsemurhalle ja toisaalta useissa keskusteluissa tuli esiin paikan ja tilan merkitys itsemurhaa tehtäessä ja sitä suunniteltaessa.

Toiseksi yleisin teema oli se, millaiset välineet (esim. eri lääkkeet, minkä tyyppiset köydet yms.) soveltuvat parhaiten itsemurhan tekemiseen ja mikä on vaivattomin ja kivuttomin tapa ottaa itsensä hengiltä., keskusteltiin runsaasti. Keskustelijat saattoivat pohtia esimerkiksi eri tyyppisten köysilaatujen kestävyyttä hirttäytyessä tai lääkkeiden yliannostusta. Yksi keskeinen näkökulma oli paitsi menetelmän ja käytettävän välineen luotettavuus, myös se, kuinka tuskaton ja nopea kuolema olisi tätä menetelmää tai välinettä käyttäen. 
Taulukko 1. Keskusteluviestien aihepïrit Ylilaudan Hikikomerokeskusteluryhmässä

\begin{tabular}{|l|l|l|}
\hline Aihe & \% & n \\
\hline Itsemurhan toteutus ja suunnittelu & 30,3 & 643 \\
\hline Itsemurhatapa ja välineet & 25,9 & 551 \\
\hline Kuolema yleisesti & 14,4 & 306 \\
\hline Avautuminen itsemurhasta & 10,3 & 218 \\
\hline Trollaus & 9,6 & 204 \\
\hline Itsemurhan tekemisen esteet & 9,5 & 201 \\
\hline Itsemurhaa vastustavat kommentit & 9,4 & 200 \\
\hline Itsemurhan motiivit & 6,3 & 134 \\
\hline Kokemukset itsemurhan yrittämisestä & 6,2 & 131 \\
\hline Jumala ja uskonnot & 4,2 & 89 \\
\hline Itsemurhaan kannustaminen & 2,5 & 53 \\
\hline Yhteensä & 100 & 2124 \\
\hline
\end{tabular}

Kolmanneksi eniten keskusteltiin kuolemasta yleensä, siihen liittyvistä odotuksista ja peloista. Monelle keskustelijalle kuolema näyttäytyi helpotuksena, poispääsynä ahdistavasta arjesta.

Myös itsemurhasta, siihen liittyvistä ajatuksista laajemmin ja peloista ja toiveista itsensä tappamisen osalta avauduttiin (10,3 \%) useissa viesteissä. Näissä viesteissä ei suoranaisesti suunniteltu itsemurhaa tai sen toteuttamista vaan enemmänkin niissä pohdittiin omaa elämää, elämäntilannetta ja erilaisia ulospääsyjä, joista itsemurha oli yksi vaihtoehto. Itsemurha oli useille keskustelijoille haave, mutta sen tekemiseen oli usein esteitä, joita pohdittiin 9,5 \%:ssa viesteistä. Tämän tyyppisissä viestiketjuissa itsemurhan tekemiseen kannustavat tai sitä ehkäisevät viestit ovat hyvä esimerkki vertaistuen tarjoamisesta. Useissa viesteissä rohkeuden puute tehdä lopullinen ratkaisu tuli myös usein esiin.

Verkkokeskusteluissa ihannoitiin usein itsemurhaa, mutta myös itsemurhaa vastustavat kommentit, joissa kehotettiin pidättäytymään lopullisesta ratkaisusta, olivat yleisiä (9,4 \%). Itsemurhaan kannustavia kommentteja kaikista analysoiduista viesteistä oli vain 2,5\%. Itsemurhaan johtavia syitä käsiteltiin 6,3 prosentissa kaikista viesteistä. Verkkokeskusteluihin osallistui myös sosiaalisesti vetäytyneitä henkilöitä, jotka kertoivat yrittäneensä itsemurhaa. Viesteistä 6,2 \% käsitteli itsemurhayrityksiä ja niiden epäonnistumisia. Myös Jumalaan ja uskontoihin liittyvää keskustelua (6,2 \%) käytiin pohdittaessa 
itsemurhan oikeutusta ja Jumalan apua tarjottiin myös pelastuksena ja vaihtoehtona vaikeassa elämäntilanteessa.

Kun aineistossa esiintyneitä ajatuksia itsemurhan tekemisestä haaveena tai itsemurhan toteuttamatta jättämisestä analysoidaan vertaistuen näkökulmasta, esiin tulee ennen muuta kaksi näkökulmaa:

1. Itsemurhan tekemiseksi saatava positiivisen vertaistuen ja kannustuksen halu

2. Itsemurhan tekemättä jättämiseen haluttu vertaistuki

Keskustelijat etsivät vertaistuen avulla vahvistusta mielipiteelleen ja vertaistuki näyttäytyy näin ollen pyrkimyksenä kognitiiviseen dissonanssiin (vrt. Festinger 1957). Jos keskustelijoilla on haave itsemurhan tekemisestä, he pyrkivät saamaan vertaistuesta vahvistusta sille.

Merkillepantavaa on, että lähes joka kymmenes (9,6 \%) viesti oli asiaton, trollaava tai vaihtoehtoisesti sisällöltään mahdoton tulkita mielekkäästi (esim. jjeeeeeee). Tämä selittynee Hikikomero-keskusteluryhmän toimintakulttuurilla, jossa moderointi on hyvin vähäistä. Ylilauta, jolla keskustelupalsta sijaitsee, on myös tunnettu foorumina, jossa vallitsee kuvalaudoille tyypillinen ronski huumori sekä myös ajoittainen trollaus. Viimeksi mainitun tarkoituksena voidaan Hikikomeron tapauksessa olettaa näiden trollien olevan muita kuin sosiaalisesti syrjäytyneitä, joiden tarkoituksena on lähinnä ilkeillä hikikomoreiden ongelmien kustannuksella. Näin voidaan päätellä siitä keskustelusta, mitä trollit saavat aikaan palstalla. Tämä on luonnollisesti edellyttänyt huolellista tulkintaa siitä, mitkä ovat yliampuvia trolleja, mitkä vakavasti otettavia viestejä. Trollaus on kuitenkin yleensä niin silmiinpistävää ja yliampuvaa, että siihen reagoidaan keskustelupalstalla ja sen tunnistaminen on helpohkoa.

Seuraavassa on analysoitu itsemurhaan liittyviä keskusteluja kvalitatiivisesti vertaistiedon ja -tuen näkökulmasta. Olemme keskittyneet ensisijaisesti itsemurhan mielekkyyteen henkilön omana valintana ja ratkaisuna, itsemurhavälineisiin ja -tapoihin ja niiden analysointiin sekä keskustelijoiden jakamiin kokemuksiin itsemurhayrityksistä eli vertaistietoon itsemurhasta.

\section{Vertaistuki ja haave itsemurhasta}

Itsemurha on verkkokeskusteluissa osalle tavoite, osalle haave ja osalle ajatus, jolla leikitellään, vaikka sitä ei viime kädessä olla todellisuudessa valmiita tekemään. 
"Itsemurha on lohduttava ajatus sillä aina kun menee paskasti... ...En tiedä tulenko koskaan tekemään sitä, mutta keinot tiedän ja sekä itsemurhaviesti ja testamentti on varmuuden vuoksi tehty jos joskus iskee vaikka äkilliset psykoosit."

Anonyymi 2019, Mietitkö itsemurhaa

Vaikka itsemurha-ajatuksella leikitellään, suuri osa keskustelijoista sanoo, ettei kykene siihen. Itsemurhaa glorifioidaan ja niitä, jotka ovat sen tehneet, pidetään sankareina. Kato, Kanba ja Teo (2019) ovat todenneet, että hikikomori-ilmiö on eristäytymistä, jonka äärimmäisenä ilmentymisenä voidaan pitää itsemurhaa.

Itsemurhan motiivit löytyvät elämäntilanteesta: yksinäisyys, heikko minäkuva, pitkään jatkunut kiusaaminen ja näihin mahdollisesti liittyvät mielenterveyden häiriöt toistuvat keskusteluissa itsemurhaa vauhdittavina tekijöinä. Elämä tuntuu tyhjältä. Myös muiden keskustelijoiden samansuuntaiset ajatukset ruokkivat tätä.

"... Mutta tähän asti se on ollu vaan suunittelua, oon kyllä miettiny ku junia ja rekkoja menny ohi, että miten ois helppooku juoksis vaan alle, mutta toisaalta pelottaa että juttu epäonnistuu"

\section{Anonyymi 2016, Oletko koskaan yrittänyt itsemurhaa}

Toisaalta rohkeuden puute ja pelko itsemurhan epäonnistumisesta toimii itsemurhan tekemisen esteenä. Silti kuolema koetaan mielekkäänä vaihtoehtona arjen harmauteen ja elämän synkkyyteen. Pelkuruus ja huoli siitä, että itsemurha toisi mielipahaa omalle perheelle, ovat usein mainittuja esteitä. Tosin osa kirjoittajista kertoo toteuttavansa suunnittelemansa itsemurhan isovanhempien kuoltua. Läheisten mielipahan ajattelu osoittaa myös sen, että vaikka tutkimuksen kohteena olevat nuoret kärsivät yksinäisyydestä, ovat mahdolliset kontaktit omaan lapsuudenkotiin ja isovanhempiin tärkeitä ja mahdollisesti jopa äärimmäistä itsetuhoisuutta estäviä seikkoja.

Toisaalta ne, jotka keskustelevat itsemurhasta, mutta myöntävät, ettei se ole reaalinen vaihtoehto, löytävät elämästä myös pieniä iloja, joiden vuoksi itseään ei kannata tappaa: 
"Seksi, pelit, leffat, sarjat, anime, auto ja toivo siitä että ehkä joku päivä voisin olla onnellinen."

Anonyymi 2019, Mietitkö itsemurhaa

Kuten edellä olevasta lainauksesta ilmenee, seikat, jotka pitävät yllä sosiaalisesti vetäytyneen henkilön halua elää, saattavat olla hyvin arkisia. Se, että voi katsoa mielekkäitä nettisisältöjä, pelata mieluisia pelejä ja katsoa televisiosta suosikkisarjoja, voi tuoda elämään sisältöä, joka estää vaipumasta pahimpaan epätoivoon. Vaikka moni hikikomori on riippuvainen verkosta ja käyttää sen palveluja hyvin paljon (Haasio 2015a), saattaa olla, että internet on eräissä tapauksissa elämässä kiinnipitävä kanava. Jos sitä ei olisi, kontaktit muuhun maailmaan ja toisiin ihmisiin olisivat entistä vähäisempiä. Verkkokeskustelut ovat nähdäksemme myös keskeinen arjessa kiinni pysymisen oljenkorsi. Sen tiedon jakaminen, että maailmassa on muitakin vertaisia, jotka ajattelevat samoin, tuo lohdutusta. Vertaistuki siitä, että muut ovat samankaltaisessa elämäntilanteessa on keskustelijoille tärkeää. Puheenvuorot siitä, mikä estää itsemurhan tekemistä, saattavat myös vertaistuen omaisesti estää henkilöä tekemästä lopullista ratkaisua. Toisaalta joissain tapauksissa vertaistuki saattaa myös kannustaa itsemurhan tekemiseen, jolloin voidaan puhua negatiivisesta vertaistuesta.

Vertaistuki voidaan ymmärtää kollektiiviseksi mielipiteiden jakamiseksi ja toisten keskustelijoiden näkemysten tukemiseksi. Aiheesta ei välttämättä muutoin voida puhua, mutta saman henkisten ihmisten keskusteluryhmä mahdollistaa mielipiteiden vaihdon.

\section{Itsemurhatavat ja välineet keskusteluissa}

Itsemurhatapoja ja itsemurhassa käytettäviä välineitä koskevaa keskustelua leimaa ennen muuta yksi ajatus: välineen ja tavan tulee olla sellainen, että se takaa varman ja kivuttoman kuoleman. Pelko itsemurhan epäonnistumisesta on yleinen ja siihen liittyy sekä henkisiä että fyysisiä pelkoja. Yhtäältä pelätään sitä, että epäonnistuminen aiheuttaa fyysisen vamman loppuelämäksi ja sitoo esimerkiksi pyörätuoliin, toisaalta taas epäonnistunut itsemurha koetaan häpeälliseksi. Ajatus, että ei edes osaa tappaa itseään ja epäonnistuu siinä, on monen keskustelijan mielestä todellisen häviäjän tunnusmerkki. Tiedontarpeissa välineisiin ja itsemurhatapaan liittyvät kysymykset korostuvat selkeästi. Näkemyksiä eri menetelmien ja välineiden eduista halutaan muilta keskustelijoilta mahdollista itsemurhan tekemistä varten. 
Keskusteluissa itsemurhatavat ja -välineiden käytännöllisyys, kivuttomuus ja se, ettei vahingoita muita ovat keskeisiä teemoja. Tästä saadaan spekulatiivista vertaistietoa ja osin myös itsemurhaa yrittäneiden henkilöiden kokemustietoa, mikä edesauttaa teon suunnittelua.

Itsemurhatapoja ja -välineitä koskeva keskustelu oli osin spekulatiivista, osin epäonnistuneiden itsemurhayritysten mukanaan tuomaan kokemustietoon perustuvaa. Luonteeltaan se on useimmiten disnormatiivista, koska valtaosa ihmisistä pitää itsemurhaa ei-toivottavana tekona. Erityisesti kannustaminen sen tekemiseen ja eri välineiden hyötyjen ja haittojen pohtiminen ovat hyviä esimerkkejä disnormatiivisesta vertaistiedosta ja -tuesta. Toisaalta itsemurhaa suunnittelevalle henkilölle vertaistieto on arvokasta esimerkiksi sen suhteen, miksi itsemurhan tekemisessä on epäonnistuttu. Käytännössä tämän tyyppiset foorumit ja verkkosivustot ovat lähes ainoa keino hankkia tällaista informaatiota. Aiheeseen liittyviä oppaita (esim. Tsurumi 2008) on olemassa, mutta ne ovat vieraskielisiä ja hankalahkosti saatavia.

Keskusteluissa tulivat esiin seuraavat itsemurhatavat ja -välineet:

- Junan alle jättäytyminen

- Hirttäytyminen

- Lääkkeiden tai lääkkeiden ja alkoholin yliannostus

- Huumeiden hankkiminen Tor-verkosta ja yliannostuksen ottaminen

- Itsensä ampuminen

- Heittäytyminen alas sillalta tms. korkealta paikalta

- Henkilöautolla rekan kanssa kolarointi

- $\quad$ Exit bag

- Itsensä kaasuttaminen

Vertaistietoa ja -tukea itsemurhan toteuttamiseen etsittiin muilta keskustelijoilta. Eniten käsiteltiin hirttäytymistä, lääkkeiden tai huumeiden yliannostusta ja junan alle jättäytymistä mahdollisina itsemurhakeinoina. Tämä tukee Lahden (2014) väitöskirjassaan esittämiä tuloksia nuorten itsemurhatavoista. 1990-luvulla hirttäytyminen yleistyi etenkin tyttöjen keskuudessa ja vuodesta 2008 alkaen liikenneitsemurhat (junan alle jättäytyminen, omalla autolla ajaminen esimerkiksi rekan alle) ovat kasvattaneet suosiota kummankin sukupuolen keskuudessa.

Merkille pantavana piirteenä junan alle jättäytymiseen menetelmänä liittyi huoli junankuljettajan mahdollisesti saamista traumoista. Itsemurhaa tehtäessä ei haluttu pahoittaa sivullisen mieltä tai aiheuttaa heille vaaratilanteita. Tämä näkökulma tuli esiin myös toisessa liikenneitsemurhia käsittelevässä aihepiirissä, omalla autolla rekan alle ajamisessa. 
Itsemurhan toteuttamista pohdittiin usein hyvin yksityiskohtaisesti. Tekniikka, millä itsemurhan toteuttaminen onnistuisi parhaiten, oli runsaasti esillä ja siihen annettiin ohjeita esimerkiksi seuraavasti:

"Varmempi tapa kuolla on mennä junaradalle makaamaan poikittain niin että asetat pääsi tai niskan/kaulan radan toisella puolella olevan metalliraiteen(pitkä pituus suunnassa oleva metalli raide) päälle. Sitten toisen puolesi asetat radalle niin että vatsasi tai vyötärösi menevät toisen raiteen(pitkä metalliraide) päältä. Jalkojesi tulisi jäädä junaradan ulkopuolelle. Näin junan pyörät leikkaavat sinulta pään, kehon, jalat toisistaan irti."

\section{Anonyymi 2016, Oletko yrittänyt itsemurhaa?}

Useissa keskusteluissa vaihdettiinkin mielipiteitä itsemurhan teknisiin kysymyksiin liittyvistä asioista puolesta ja vastaan. Eri menetelmien käyttökelpoisuutta ja niihin liittyviä ongelmia pohdittiin myös paljon. Esimerkiksi itsensä ampuminen koettiin usein hankalana aseiden vaikean saatavuuden takia. Lääkkeiden ja huumeiden yliannostuksen osalta merkillepantavaa oli se, että useissa viesteissä viitattiin Tor-verkon kauppapaikkoihin, joista voi helposti ostaa huumeita. Onkin mahdollista, että itsemurhien tekotapana esimerkiksi yliannostukset voivat lisääntyä, sillä huumeiden saanti verkosta on hyvin helppoa (Haasio, Harviainen \& Savolainen 2020).

Itsemurhaan liittyvien ohjeiden ja tekotapojen pohdinta sisältää eettisen näkökulman siitä, tuottaako se toisille traumoja (esim. junan alle jättäytyminen) ja toisaalta siinä pohditaan kivuttomuutta, nopeutta ja tehokkuutta. Tämän tyyppisen tiedon jakaminen voi omalta osaltaan vaikuttaa siihen, mitä itsemurhatapaa yritetään. Kyse on vertaistiedosta, joka ohjaa päätöksentekoa mahdollisen itsemurhan toteuttamisessa valittavan toteutustavan suhteen.

\section{Kokemukset itsemurhan yrittämisestä}

Hikikomero-sivustolla kuvattiin kokemuksia itsemurhan yrittämisestä ambivalentisti. Toisaalta esiin nousi kokemus epäonnistuneen itsemurhayrityksen aiheuttamasta turhautumisesta ja pettymisestä omaan pelkuruuteen ja viime hetkellä jänistämiseen. Toisaalta itsemurhan yrittämisen epäonnistuminen koettiin helpotuksena, koska itsemurhaa hautonut hikikomori ei kokenutkaan olevansa varma siitä, haluaako kuolla vai jatkaa elämää. Lisäksi itsemurhayritys epäonnistui itsesuojeluvaiston puuttuessa tilanteen kulkuun. Näiden 
yksittäisten näkemysten jakamista voidaan pitää muiden keskustelijoiden kannalta merkittävänä vertaistiedon ja -tuen lähteenä.

"Sillä hetkellä en halunnutkaan riippua narun jatkeena, vaikka kaikki olikin valmiina."

\section{Anonyymi 2017, Oletko yrittänyt itsemurhaa?}

Muutama hikikomori kuvasi yrittäneensä itsemurhaa useita kertoja, mutta jänistäneensä joka kerta. Jänistäminen liittyi sekä tilanteen pelottavuuteen että myös epävarmuuteen, haluaako todella luopua elämästä. Epävarmuus itsemurhan jälkeisestä elämästä tai olotilasta pelotti liikaa ja esti itsemurhan toteuttamisen.

"Pari kertaa lähdin junaradalle makoilemaan, mutta junan lähestyessä rupesi kuumottamaan liikaa, eikä voinut kuin käppäillä kotiin pettyneenä."

\section{Anonyymi 2017, Oletko yrittänyt itsemurhaa?}

Muutama toi myös esiin, että itsemurhayrityksen jälkeen he alkoivatkin arvostaa elämäänsä aikaisempaa enemmän. Kuoleman läheisyys sai heidät pohtimaan elämän tarkoitusta ja mielekkyyttä. Elämää ja kuolemaa alettiin pohtia arvojen ja elämänsisältöjen näkökulmasta. Elämän tarkoitusta saatettiin pohtia elämän tyhjyyden tai tarkoituksettomuuden kautta sekä vertaillen oman elämän mielekkyyttä julkisuuden henkilöiden tai läheisten elämän mielekkyyteen. Elämän tyhjyyden kuvaaminen liittyi usein läheisten ihmisten, perheen tai parisuhteen puuttumiseen tai vaikeisiin kiusaamis- tai kaltoinkohtelukokemuksiin, jotka olivat herättäneet ajatuksen oman elämän arvottomuudesta. Vaikeista kokemuksista huolimatta oma elämä koettiin arvokkaana.

Itsemurhayrityksen epäonnistuminen koettiin turhauttavana sen johtaessa psykiatriseen osastohoitoon. Hoitoon joutuminen koettiin omaa vapautta ja itsenäisyyttä rajoittavana sekä ahdistavana asiana. Se herätti myös häpeää ja syyllisyyttä. Erityisesti syyllisyyttä koettiin siitä, millaista huolta ja häpeää psykiatriseen hoitoon joutuminen aiheutti läheisille. Lisäksi terveydenhuollon ammattilaisten pelättiin lisäävän omaa ahdistuneisuutta saarnaavalla ja syyllistävällä asenteella.

Itsemurhayrityksen epäonnistuminen koettiin turhauttavana erityisesti silloin, kun epäonnistuminen aiheutti pysyviä henkisiä ja sosiaalisia toimintakyvyn vajauksia ja oma elämäntilanne muuttui epäonnistuneen yrityksen myötä entistä pahemmaksi. 
"Fentanyyliä piikitin suoneen ja seurauksena vasemman jalan toimintakyvyttömyys ja muistivaikeudet."

Anonyymi 2017, Oletko koskaan yrittänyt itsemurhaa

Muutama Hikikomero-sivustolle kirjoittanut koki itsemurhayrityksen epäonnistumisen omaa itsetuntoa edelleen alentavana. Se lisäsi ankaraa suhtautumista itseen. Toisaalta hikikomoreilla oli kipeä tarve tulla kuulluksi, nähdyksi ja huomatuksi. Tällaisissa tapauksissa itsemurhayrityksen kautta haettiin huomiota ja apua.

Itsemurhayrityksen epäonnistuminen johtui yleensä siitä, että itsemurhaa ei ollut suunniteltu ja valmisteltu riittävän perusteellisesti tai oma mieli ei ollut vielä riittävän synkkä. Osa hikikomoreista koki itsemurhan onnistumisen edellyttävän tietynlaista "moodia."

"Itsemurhaprosessista monet eivät ymmärrä, että se on pitkä prosessi... ... Päätös sisältää massiivisen määrän analysointia ja itsetutkiskelua. Myöskin oman elämänhistorian läpikäynnin sekä anteeksiannon niin itselleen kuin muillekin kakista synneistä, mitä koskaan on tapahtunut. Tässä tehdään välit itsensä kanssa täysin selviksi. Lopputuloksena on uskomattoman lämmin, rauhallinen, mukava, vihaton, peloton tunne. On onnellisempi kuin koskaan?"

\section{Anonyymi 2017, Oletko yrittänyt itsemurhaa?}

Itsemurhan tekemiseen liittyvä filosofinen pohdinta on esimerkki vertaistuesta: onko ratkaisu eettisesti perusteltu? Toisaalta epäonnistumisiin liittyvät kokemukset esimerkiksi itsemurhatavan väärän valinnan suhteen ohjaavat mahdollisten itsemurhakandidaattien tiedonhankintaa erilaisten itsemurhatapojen ja -välineiden soveltuvuudesta ja synnyttävät näin tiedontarpeita tähän liittyen.

\section{Keskustelua}

Vertaistuen ja vertaistiedon merkitys hikikomoreille on suuri, kuten Haasio (2015b) on havainnut. Tämä pätee myös itsemurhiin liittyvään keskusteluun. Puhumalla itsemurha-ajatuksista saadaan vertaistukea, vastakaikua ja ymmärrystä omille mielipiteille. Valitettavaa on se, että useissa tapauksissa Hikikomero-palstalta saatu vertaistuki ja vertaistieto ovat luonteeltaan negatiivisia ja jopa rohkaisevat yrittämään itsemurhaa. Itsemurhan tehnyttä henkilöä 
saatetaan ihailla ja kunnioittaa ja pitää rohkeana. Lewandowskin ym. (2011), Gowenin ym. (2012) ja Millerin ym. (2015) mukaan internetin kautta saatu vertaistieto voi olla joko positiivista tai negatiivista. Keskeistä on myös vertaistiedon jakaminen, mahdollisuus antaa ja saada tietoa. Internetistä löydettävää vertaistietoa voidaan arvioida sen hyödyllisyyden näkökulmasta. (Prescott, Rahbone \& Brown 2020.) Myös Chuang ja Yang (2012) korostavat internetistä saatavan vertaistiedon ja vertaistuen kriittistä tarkastelua eri näkökulmista. Westerlund (2013) on todennut, että itsemurhaa käsittelevissä verkkokeskusteluissa saatu vertaistuki saattaa myös tehdä itsemurhan toteuttamisen vähemmän pelottavaksi ratkaisuksi. Tämä näkyy Hikikomeron keskusteluissa itsemurhaan rohkaisevissa viesteissä. Kun Hikikomero-palstan keskusteluja tarkastellaan kokonaisvaltaisesti vertaistuen ja -tiedon kontekstissa, voidaan niiden hankkimisen nähdä olevan yksi keskeinen motiivi tiedontarpeiden tyydyttämisen ja tiedonjakamisen osalta.

Viime kädessä itsemurhaan liittyvän vertaistiedon jakamista ja keskustelujen vertaistukea voidaan pitää ensisijaisesti luonteeltaan disnormatiivisena informaationa tai pimeänä tietona lukuun ottamatta sitä vertaistukea, jossa kehotetaan luopumaan itsemurha-ajatuksista. Viesteissä ilmenee hyvin disnormatiiviselle informaatiolle tyypillinen yhteiskunnan enemmistön näkemysten vastaisen informaation tarve, jota voidaan pitää moraalisesti arveluttavana ja perinteisten ihmisen elämää kunnioittavien normien, arvojen ja asenteiden vastaisena.

Informaatiotutkimuksen näkökulmasta erityisesti disnormatiivisen informaation ja pimeän tiedon näkökulmasta vertaistietoa ja vertaistukea käsittelevän empiirisen tutkimuksen tarve on selkeä. Se mahdollistaa tämän tyyppisen informaation mahdollisten erityispiirteiden ja siihen liittyvän informaatiokäyttäytymisen havainnoinnin. Rikolliseen tai muutoin normien vastaiseen tiedonhankintaan ja siihen liittyvään informaatiokäyttäytymiseen liittyvä empiirinen tutkimus on toistaiseksi ollut hyvin vähäistä.

Artikkelimme havainnollistaa myös vertaistiedon merkitystä ja vertaistuen tärkeyttä päätöksenteossa. Näitä teemoja tulisi jatkotutkimuksessa analysoida tarkemmin. Myös muut disnormatiivisen informaation tai pimeän tiedon empiiriset tutkimukset ovat nähdäksemme jatkossa tärkeitä tämän tyyppisen informaation erityisluonteen ymmärtämiseksi. 


\section{Kirjallisuus}

Burnett, S., \& Lloyd, A. (2020). Hidden and forbidden: conceptualising Dark Knowledge. Journal of documentation, 76(6), 1341-1358. https://doi .org/10.1108/JD-12-2019-0234

Chatman, E. A. (1987). The information world of low-skilled workers. Library and Information Science Research, 9(4), 265-283.

Chatman, E. A. (1990). Alienation theory: Application of a conceptual framework to a study of information among janitors. $R Q, 29(3), 355-368$.

Chatman, E. A. (1991). Life in a small world: Applicability of gratification theory to information seeking behavior. Journal of the American Society for Information Science, 42(6), 438-449.

Chu, C., Klein, K. M., \& Buchman-Schmitt, J. M., \& Hom, M. A. \& Hagan, C. R. \& Joiner, T. E. (2015). Routinized assessment of suicide risk in clinical practice: An empirically informed update. Journal of clinical psychology, 71(12), 1186-1200. https://doi.org/10.1002/ jclp. 22210

Chuang, K. Y., \& Yang, C. C. (2012). Interaction Patterns of Nurturant Support Exchanged in Online Health Social Networking. Journal of Medical Internet Research, 14(3), e54. https:// doi.org/10.2196/jmir.1824

Dervin, B. (1999). On studying information seeking methodologically: The implications of connecting metatheory to method. Information Processing and Management, 35(6), 727-750. https://doi.org/10.1016/s0306-4573(99)00023-0

Ferguson, R.-H. (2017). Offline 'stranger' and online lurker: methods for an ethnography of illicit transactions on the darknet. Qualitative research, 17(6), 683-698. https://doi. org/10.1177/1468794117718894

Festinger, L. (1957). A theory of cognitive dissonance. Stanford University Press.

Glaser, B., \& Strauss, A. L. (1967). The Discovery of Grounded Theory. Sociology Press.

Gowen, K., Deschaine, M., Gruttadara, D., \& Markey, D. (2012). Young adults with mental health conditions and social networking websites: Seeking tools to build community. Psychiatric Rehabilitation Journal, 35(3), 245-250. https://doi.org/10.2975/35.3.2012.245.250

Haasio, A. (2015a). Toiseus, tiedontarpeet ja tiedon jakaminen tietoverkon "pienessä maailmassa": tutkimus sosiaalisesti vetäytyneiden henkilöiden informaatiokäyttäytymisestä. Tampere University Press (Acta Universitatis Tamperensis 2082). Väitöskirja. http://urn.fi/ URN: ISBN: 978-951-44-9878-7

Haasio, A. (2015b). Disnormatiivinen ja normatiivinen informaatio. Informaatiotutkimus, 34(4). https://journal.fi/inf/article/view/53512

Haasio, A. (2015c). Vertaistukea verkosta: Hikikomero-keskustelupalsta sosiaalisesti vetäytyneiden tiedonhankintakanavana. WiderScreen 3/2015. http://widerscreen.fi/assets/AriHaasio2-2015.pdf

Haasio, A. (2018). Hikikomorit. Avain.

Haasio, A., Harviainen, J. T., \& Savolainen, R. (2020). Information needs of drug users on a local dark Web marketplace. Information Processing \& Management, 57(2), 102080. https :// doi.org/10.1016/j.ipm.2019.102080 
Haasio, A., \& Naka, H. (2019). Information needs of the Finnish and Japanese hikikomori: a comparative study. Qualitative and Quantitative Methods in Libraries, 8(4), 509-523. http:// www.qqml.net/index.php/qqml/article/view/533

Haasio, A., \& Salminen-Tuomaala, M. (2020). Suicide motives and protective factorscontributions from a hikikomori discussion board. Issues in Mental Health Nursing. https: // doi.org/10.1080/01612840.2020.1817209

Hagihara, A., \& Miyazaki, S., \& Abe, T. (2012). Internet suicide searches and the incidence of suicide in young people in Japan. European Archives of Psychiatry and Clinical Neuroscience, 262(1), 39-46. https://doi.org/10.1007/s00406-011-0212-8

Heimo, A. (2013). Meemi tulee. Folkloristi, oletko valmis?. Elore, 20(2). https://doi. org/10.30666/elore.79087

Helasvuo, M.-L., \& Johansson, M., \& Tanskanen, S.-K. (2014). Johdatus digitaaliseen vuorovaikutukseen. Teoksessa M.-L. Helasvuo, M. Johansson \& S.-K. Tanskanen (toim.), Kieli verkossa: Näkökulmia digitaaliseen vuorovaikutukseen (pp. 9-28). Suomalaisen Kirjallisuuden Seuran toimituksia 1402. Suomalaisen Kirjallisuuden Seura.

Highton-Williamson, E., Priebe, S., \& Giacco, D (2015). Online social networking in people with psychosis: a systematic review. International Journal of Social Psychiatry, 61(1), 92-101. https://doi.org/10.1177/0020764014556392

Husu, H.-M., \& Välimäki, V. (2017). Staying inside: social withdrawal of the young, Finnish 'Hikikomori'. Journal of Youth Studies, 2O(5), 605-621. https://doi .org/10.1080/13676261. 2016.1254167

Itsemurhat (2019). Findikaattori. Päivitetty 16.12.2019. https: //findikaattori.fi/fi/10

Järvinen-Tassopoulos, J. (2011). Pelaavien naisten nettikeskustelujen käytön ja analyysin eettiset haasteet.” Teoksessa S. Lakomäki, P. Latvala \& K. Laurén (toim.), Tekstien rajoilla: Monitieteisiä näkökulmia kirjoitettuihin aineistoihin (pp. 202-229). Suomalaisen Kirjallisuuden Seura.

Kato, T. A., Kanba, S., \& Teo, A. R. (2019). Hikikomori: Multidimensional understanding, assessment, and future international perspectives. Psychiatry and clinical neurosciences, 73(8), 427-440. https://doi.org/10.1111/pcn.12895

Kato, T.A., Shinfuku, N., \& Tateno, M. (2020). Internet society, internet addiction, and pathological social withdrawal: the chicken and egg dilemma for internet addiction and hikikomori. Current opinion in psychiatry, 33(3), 264-270. https://doi.org/10.1097/YC0.0000000000000601

Kato, T. A., Tateno, M., Shinfuku, N., Fujisawa, D., Teo, A. R., Sartorius, N., . . Kanba, S. (2012). Does the 'hikikomori' syndrome of social withdrawal exist outside Japan? A preliminary international investigation. Social psychiatry and psychiatric epidemiology, 47(7), 1061-1075. https://doi.org/10.1007/s00127-011-0411-7

Kozinets, R. V. (2010). Netnography: Doing Ethnographic Research Online. Sage.

Kozinets, R. V. (2015). Netnography. Teoksessa P. H. Ang \& R. Mansell (toim.), The International Encyclopedia of Digital Communication and Society. https://doi.org/10.1002/ 9781118767771.wbiedcs067

Krysinska, D. (2007). Hikikomori (social withdrawal) in Japan: Discourses of media and scholars; Multicausal explanations of the phenomenon. University of Pittsburgh. http:// d-scholarship.pitt.edu/id/eprint/9520 
Kummervold, P. E., Gammon, D., Bergvik, S., Johnsen, J.-A. K., Hasvold, T., \& Rosenvinge, J. H. (2002). Social support in a wired world: use of online mental health forums in Norway. Nordic Journal of Psychiatry, 56(1), 59-65. https://doi.org/10.1080/08039480252803945

Lahti, A. (2014). Epidemiological study on trends and characteristics of suicide among children and adolescents in Finland. Oulun yliopisto. Väitöskirja. http://urn.fi/urn:isbn: 9789526205571

Lasgaard, M., Goossens, L., \& Elklit, A. (2011). Loneliness, depressive symptomatology, and suicide ideation in adolescence: cross-sectional and longitudinal analyses. Journal of Abnormal Child Psychology, 39(1), 137-150. https://doi.org/10.1007/s10802-010-9442-x

Leivo, T., Mutanen, M., \& Nieminen-Sundell, R. (toim.) (2009). Diginatiivit, työ, kansalaisuus. Sitra. https://www.sitra.fi/julkaisut/diginatiivit-tyo-kansalaisuus/

Lewandowski, J., Rosenberg, B. D., Parks, M. J., \& Siegel, J. T. (2011). The effect of informal social support: face-to-face versus computer-mediated communication. Computers in Human Behavior, 27(5), 1806-1814. https://doi.org/10.1016/j.chb.2011.03.008

Linnakangas, R., \& Suikkanen, A. (2004). Varhainen puuttuminen. Mahdollisuus nuorten syrjäytymisen ehkäisemisessä. Sosiaali- ja terveysministeriön selvityksiä, 2004:7. Sosiaalija terveysministeriö. http://urn.fi/URN: NBN:fi-fe201504223982

Marchant A., Hawton K., Stewart A., Montgomery P., Singaravelu V., Lloyd, K., .. . John, A. (2017). A systematic review of the relationship between internet use, self-harm and suicidal behaviour in young people: The good, the bad and the unknown. PLOS ONE, 12(8), e0181722. https:// doi.org/10.1371/journal. pone. 0181722

Martin, J., \& Christin, N. (2016). Ethics in cryptomarket research. International Journal of Drug Policy, 35, 84-91. https://doi.org/10.1016/j.drugpo.2016.05.006

Marttunen, M., Haravuori, H., \& Santalahti, P. (2014). Lasten ja nuorten mielenterveys ja syrjäytyminen. Sosiaalilääketieteellinen aikakauslehti, 51(3). https://journal.fi/sla/article/ view/48317

Miller, B. J., Stewart, A., Schrimsher, J., Peeples, D., \& Buckley, P. F. (2015). How connected are people with schizophrenia? Cell phone, computer, email, and social media use. Psychiatry Research, 225(3), 458-463. https://doi.org/10.1016/j.psychres.2014.11.067

Naslund, J. A., Grande, S. W., Aschbrenner, K. A. \& Elwyn G. (2014). Naturally occurring peer support through social media: the experiences of individuals with severe mental illness using YouTube. PloS ONE, 9(10), e110171. https://doi.org/10.1371/journal. pone. 0110171

Naslund, J. A., Aschbrenner, K. A., Marsch, L. A., \& Bartels, S. J. (2016). The future of mental health care: peer-to-peer support and social media. Epidemiology and Psychiatric Sciences, 25(2), 113-122. https://doi.org/10.1017/S2045796015001067

Nylund, M. (2005). Vertaisryhmät kokemuksen ja tiedon jäsentäjinä. Teoksessa M. Nylund \& A. B. Yeung (toim.), Vapaaehtoistoiminta. Anti, arvot ja osallisuus (pp. 195-213). Vastapaino.

Ohashi, N. (2008). Exploring the psychic roots of Hikikomori in Japan. ProQuest.

Ovejero, S., Caro-Cañizares, I., de León-Martínez, V., \& Baca-Garcia, E. (2014). Prolonged social withdrawal disorder: a hikikomori case in Spain. International Journal of Social Psychiatry, 6o(6), 562-565. https://doi.org/10.1177\%2F0020764013504560 
Padmanathan, P., Biddle, L., Carroll, R., Derges, J., Potokar, J., \& Gunnell, D. (2018). Suicide and Self-Harm Related Internet Use: A Cross-Sectional Study and Clinician Focus Groups. Crisis, 39, 469-478. https://doi.org/10.1027/0227-5910/a000522

Prescott, J., Rathbone, A. L., \& Brown, G. (2020). Online peer to peer support: Qualitative analysis of UK and US open mental health Facebook groups. Digital Health, 6, 1-7. https :// doi.org/10.1177/2055207620979209

Ranieri, F. (2018). Psychoanalytic Psychotherapy for Hikikomori Young Adults and Adolescents. British Journal of Psychotherapy, 34(4), 623-642. https://doi.org/10.1111/bjp.12398

Recupero, P. R., Harms, S. E., \& Noble, J. M. (2008). Googling suicide: Surfing for suicide information on the Internet. The Journal of Clinical Psychiatry, 69(6), 878-888. https:// psycnet.apa.org/record/2009-03168-001

Repper, J., \& Carter, T. (2011). A review of the literature on peer support in mental health services. Journal of mental health, 2O(4), 392-411. https://doi.org/10.3109/09638237.2011.583947

Ruokolainen, H. (2018). Misinformation as a Barrier to Social Inclusion in the Context of Asylum Seekers in Finland. Teoksessa H. Li, R. Suomi, Á. Pálsdóttir, R. Trill \& H. Ahmadinia (toim.), Proceedings of the Seventh International Conference on Well-Being in the Information Society: Fighting Inequalities (WIS 2018) (pp. 71-74). Turku Centre for Computer Science. http: //urn. fi/URN: ISBN: 978-952-12-3727-0

Saito, T. (1998). Social Withdrawal (Shakaiteki Hikikomori). PHP Shinsho (in Japanese).

Salman, S., Idrees, J., Hassan, F., Idrees, F., Arifullah, M., \& Badshah, S. (2014). Predictive factors of suicide attempt and non-suicidal self-harm in emergency department. Emergency, 2(4), 166-169. https://www.ncbi.nlm.nih.gov/pmc/articles/PMC4614564/

Sarchione, F., Santacroce, R., Acciavatti, T., Cinosi, E., Lupi, M., Di Giannantonio, M. (2015). Hikikomori, clinical and psychopathological issues. Research and Advances in Psychiatry, $2,21-7$.

Savolainen, R. (1993). Elämäntapa, elämänhallinta ja tiedonhankinta: Arkielämän ei-ammatillisen tiedon hankinnan tutkimuksen viitekehityksen hahmottelua. Tampereen yliopisto.

Savolainen, R. (1995). Everyday life information seeking: approaching information seeking in the context of "way of life". Library \& Information Science Research, 17(3), 259-294. https : // doi.org/10.1016/0740-8188(95)90048-9

Schinka, K., Van Dulmen, M., Mata, A., Bossarte, R., \& Swahn, M. (2013). Psychosocial predictors and outcomes of loneliness trajectories from childhood to early adolescence. Journal of Adolescence, 36(6), 1251-1260. https://doi.org/10.1016/j. adolescence. 2013.08.002

Sedgwick, R., Epstein, S., Dutta, R., \& Ougrin, D. (2019). Social media, internet use and suicide attempts in adolescents. Current Opinion in Psychiatry, 32(6), 534-541. https://dx. doi. org/10.1097\%2FYC0.00000000000000547

Suomen virallinen tilasto (SVT): Kuolemansyyt (2017). Itsemurhien määrässä kasvua edellisvuosista. Tilastokeskus. http://www.stat.fi/til/ksyyt/2017/ksyyt_2017_2018-12-17_kat_006_ fi.html

Suwa, M., \& Suzuki, K. (2013). The phenomenon of "hikikomori" (social withdrawal) and the socio-cultural situation in Japan today. Journal of Psychopathology, 19, 191-198. https ://www. jpsychopathol.it/wp-content/uploads/2015/07/01b-Suwa1.pdf 
Tajan, N. (2015). Social withdrawal and psychiatry: A comprehensive review of Hikikomori. Neuropsychiatrie de l'Enfance et de l'Adolescence, 63(5), 324-331. https://doi. org/10.1016/j.neurenf.2015.03.008

Tajan, N., Yukiko, H., \& Pionnié-Dax, N. (2017). Hikikomori: the Japanese Cabinet Office's 2016 survey of acute social withdrawal. The Asia Pacific Journal, 15(5). https://apjjf. org/2017/05/Tajan.html

Tan, M. P. J., Lee, W., \& Kato, T. A. (2020). International experience of hikikomori (prolonged social withdrawal) and its relevance to psychiatric research. BJPsych International, 1-3. https://doi.org/10.1192/bji.2020.20

Tapscott, D., \& Barry, B. (2009). Grown up digital: How the net generation is changing your world (Vol. 200). McGraw-Hill.

Teo, A. R. (2010). A new form of social withdrawal in Japan: a review of hikikomori. International Journal of Social Psychiatry, 56(2), 178-185. https://doi.org/10.1177\%2F0020764008100629

Tilastokeskus (2019). Kuolemansyyt. http://wWw.stat.fi/tup/suoluk/suoluk_terveys.html \#Kuolemansyyt Luettu 28.7.2020.

Tsurumi, W. (2008). Kanzen Jisatsu Manyuaru, The Complete Suicide Manual. Tōkyō Ōta Shuppan.

Turtiainen, R., \& Östman, S. (2009). Tavistaidetta ja verkkoviihdettä: Omaehtoisten verkkosisältöjen tutkimusetiikkaa. Teoksessa M. Grahn \& M. Häyrynen (toim.), Kulttuurituotanto: Kehykset, käytännöt ja prosessit (pp. 336-358). Tietolipas 230. Suomalaisen Kirjallisuuden Seura.

Uchida, C. (2010). Apathetic and Withdrawing Students in Japanese Universities-with Regard to Hikikomori and Student Apathy-. Journal of medical and dental sciences, 57(1), 95-108. https://doi.org/10.11480/jmds. 570111

Vainikka, E. (2020). The anti-social network: Precarious life in online conversations of the socially withdrawn. European Journal of Cultural Studies, 23(4), 596-610. https://doi. org/10.1177/1367549418810075

Vainikka, E., \& Harju, A. (2019). Anonyymien keskustelupalstojen julkisuus: Marginaaliin jääneiden vertaistukea ja yhteiskuntakritiikkiä. Media \& viestintä, 42(2), 99-121. https://doi. org/10.23983/mv.83374

Valaskivi, K. (2012). Autenttisuutta osmoosilla - japanilainen populaarikulttuuri osana elämää. Teoksessa M. Salasvuo, J. Poikolainen \& P. Komonen (toim.), Katukulttuuri: Nuorisoesiintymiä 20oo-luvun Suomessa (pp. 33-63). Nuorisotutkimusseuran/Nuorisotutkimusverkoston julkaisuja 124. Nuorisotutkimusverkosto.

Westerlund, M. (2013). Talking suicide: online conversations about a taboo subject. Nordicom Review, 34(2), 35-46. https://doi.org/10.2478/nor-2013-0052

Whiteman, N. (2012). Undoing Ethics: Rethinking Practice in Online Research. Springer.

Yong, R., \& Nomura, K. (2019). Hikikomori is most associated with interpersonal relationships, followed by suicide risks: a secondary analysis of a national cross-sectional study. Frontiers in psychiatry, 1O, 247. https://doi.org/10.3389/fpsyt.2019.00247

Zechner, M., \& Haasio, A. (2016). Seksuaalisuus sosiaalisesti vetäytyneiden nuorten verkkopuheessa. Suomen seksologinen seura ry. http://urn.fi/URN:NBN : fi: amk-2017053011105 